\title{
ICT in Higher Education: Wiki-based Reflection to Promote Deeper Thinking Levels
}

\author{
Akinul Islam Jony \\ American International University - Bangladesh (AIUB), Dhaka, Bangladesh \\ Email: akinul@gmail.com \\ Md. Sadekur Rahman and Yousuf Mahbubul Islam \\ Daffodil International University, Dhaka, Bangladesh \\ Email: \{sadekur.cse, ymislam\}@ daffodilvarsity.edu.bd
}

\begin{abstract}
The main purpose of higher education is to produce skilled graduates so that they can think critically and solve real world problems. Presenting a group based solution in a face-to-face class is a common activity in the higher education classroom where other students/peers can actively participate in the follow-up question/answer sessions. Working out a solution together as a group engages students' independent thinking ability and promotes active learning. This means, that they have the opportunity to reflect on their own thinking and take it to deeper levels of thinking. However, recent trends show that online support to the higher education class - a form of blended learning is growing day by day. This paper proposes a wiki-based (one of the ICT tools) reflection method to follow up regular existing face-to-face classroom presentation activities to promote deeper thinking levels of students in higher education. In this article, Lee's Model of thinking levels is-used for analyzing the thinking levels of students during their wiki work. The findings of this research work (through experiments) show that the wiki-based reflection method could be an effective way to promote thinking levels of students and hence can be used as a blended learning model to promote reflective and in-depth thinking.
\end{abstract}

Index Terms - Online Learning, E-learning, Technology Enhanced Learning, Higher Education, Blended Learning, Thinking Levels.

\section{INTRODUCTION}

Class presentation is a popular activity in higher education where students can be actively involved in the follow-up question/answer (Q/A) session. Traditionally, the question pattern in higher education uses common verbs like describe, list, define, or state something based on a specific topic, where they do not need to engage their thinking, except memorize the knowledge and echo (recall) the same knowledge, i.e., involve lower order thinking (LOT, Bloom's Taxonomy). In some cases, they have been asked to explain or calculate something where they need to rationalize their thinking with the knowledge. The purpose of higher education is to produce skilled graduates, who could become real world problem solvers, critical thinkers or have the ability of think critically. Hence, to accomplish this purpose higher education institutes need to encourage students to reflect on their own thinking. In this regard, classroom group presentations that require a solution to a real problem would be helpful to engage students and promote active learning.

A key element of classroom or face-to-face learning is the social and communicative interactions between student and teacher, and student and student. The fundamental learning activities of a student is to ask a question, to share an opinion, or to disagree with a point of view, which are usually carried out through conversation, discussion, and debate among students and/or between teachers and students. Eventually, a learning objective is achieved by performing these faceto-face classroom learning activities. Thus, online learning requires amendments by teachers as well as students for successful interactions to occur towards reflective learning. Generally online education/learning substitutes classroom face-to-face interaction with discussion boards, blogs, wiki, synchronous chat, electronic bulletin boards, and e-mails. Some scholars suggest that interaction in an online learning environment promotes student-centered learning, encourages wider student participation, and produces more in-depth and reasoned discussions than a conventional face-to-face classroom setting does $[12,25]$. Learning or acquisition of knowledge and thinking are interrelated lifelong processes [5]. So, one must learn how to refine and adjust one's thinking and reflects his or her own thinking beyond the knowledge to add depth and substance to his or her own knowledge. By continuous practice with time, one can get higher at making more thoughtful observations and judgments and can apprehend how values are reflected in thinking and behaving [29]. Thus, if it is possible to nurture the learning and thinking processes, it will continue for a lifetime.

In addition, online involvement rates in education (a form of blended learning) are growing at much faster rates than the traditional classroom or face-to-face learning; specifically, in higher education in all over the world. Hence, the research question of this paper is outlined as "Is it possible to promote thinking levels 
using ICT tools?", that means, can additional questions on class work or class presentations given in a web based ICT tool scaffold to help students move into higher levels of thinking? To address this issue, wiki is chosen as an ICT tool for higher education where students participate virtually to post their Q/A based on a poster presentation. Finally, to outline the findings of this research work, the popular Lee's Model [13] of thinking levels is used to analyze the student's data set collected from the wikibased poster presentations.

The rest of the paper is structured as follows: in section 2 , related works have been stated. Section 3 describes the research methodology applied in this paper. Section 4 illustrates the findings of this research work by analyzing the results from the experiment. Finally, section 5 concludes the paper.

\section{RELATED WORKS}

Philosophy of learning based on reflection begins from everyday experience at a higher education institution. Reflection of thinking can help students to strengthen learning and professional efficiency which eventually helps them to think beyond the knowledge. Hence, reflection of thinking activates learning, self-analysis, as well as solution of real world problems. So, the learning in higher education needs to emphasize on this goal, i.e. to produce critical thinker.

Literature suggests that the importance of developing critical thinking skills and abilities at higher education is required for producing skilled graduates. Thus, improving students' critical thinking abilities has become a primary goal for higher education institutes. The analysis of scientific sources $[22,4,14,3,15,16,2]$ showed that by reflective learning a student is empowered to coordinate theoretical and practical knowledge, to create own personal thinking beyond the knowledge and understanding about future professional activity at a higher education institution.

One of the teaching method is direct instruction which first coined by Rosenshine [19]. This is teacher-centered method where teachers present new information followed by classroom or face-to-face activities [23]. Another method is problem-based learning where students are given with problems to work in small and self-directed learning groups to investigate and develop solutions to a given problem [1]. The major advantages of this method are to develop higher-level thinking skills [6], and problem solving skills [7, 9] of students. This almost similar to our wiki-based learning where students can improve their thinking levels based on a given problem (which is poster presentation of a problem in this article) on a wiki as an ICT tool in higher education. On the other hand, video-based learning could be helpful especially to foreign students with weaker language skills, because they prefer Web-based tutorials instead of traditional class lectures [27]. As our wiki-based reflection is web based, hence, students also can avail this benefit by this method.
Besides this, in a cooperative or collaborative learning method usually students work in small groups to accomplish a task. Research [11] shows that, students participating in this method perform better than the students in competitive and individualistic learning environments in terms of achievements and attitudes towards learning. In our method, students are also given a problem (poster presentation) in groups on wiki, and experiments shows that this collaborative learning helps student to improve their thinking levels.

Moreover, blended e-learning is the special case of learning which combined face-to-face learning, elearning and self-study. This also referred to as hybrid learning [20, 28], or mixed mode learning [18]. There are various models of blended learning such as, Flex model, Rotation model, Self-Blend model, and Enriched Virtual model [8, 10, 26]. In Flex model, delivering mode is instruction based where teacher provides support as needed-basis. Rotation model is variation of different learning stations, where students rotate on a fixed schedule or at the teacher's discretion and move to online learning/work. In Self-Blend model, students are given the opportunity to take online courses to supplement their traditional courses, where instructions are given by online teachers. And in Enriched Virtual model, teachers deliver all curricula on an online platform, where students work remotely for most of the part. Whereas, our proposed model is problem-based given by a teacher on a wiki (web-based ICT tool), where students participate for learning and promote their thinking level especially in higher education.

\section{METHODS}

This section contains the description of methodology of the proposed wiki-based reflection model presented in this paper. Firstly, the Lee's model of thinking levels is discussed which is used for checking the thinking levels of students. Secondly, the description of datasets is presented which is used to experiment the proposed model. Finally, how the dataset is analyzed to show the thinking levels of students is discussed. These three parts of the methodology is presented in the following three subsections respectively.

\section{A. Models}

To experiment the wiki-based reflection to promote thinking level, we used the popular Lee's model [13], which have three levels of thinking (see Table 1).

Table 1. Lee's Model

\begin{tabular}{|c|c|c|l|}
\hline $\begin{array}{c}\text { Levels of } \\
\text { Thinking }\end{array}$ & $\begin{array}{c}\text { Degree of } \\
\text { Levels }\end{array}$ & Lee's Model & Description of Lee's Model \\
\hline Level 1 & Lowest & Recall & $\begin{array}{l}\text { Echo (recall) the same } \\
\text { content (knowledge) }\end{array}$ \\
\hline Level 2 & Intermediate & Rationalization & $\begin{array}{l}\text { Rationalize his or her } \\
\text { thinking with the content } \\
\text { (knowledge) }\end{array}$ \\
\hline Level 3 & Highest & Reflectivity & $\begin{array}{l}\text { Reflect his or her own } \\
\text { thinking beyond the content } \\
\text { (knowledge) }\end{array}$ \\
\hline
\end{tabular}


In Table 2, another model similar to Lee's Model of thinking level called Bloom's Taxonomy of Educational Objectives has more specific levels of thinking. It has six levels of thinking.

Table 2. Bloom's Taxonomy of Educational Objectives

\begin{tabular}{|c|c|c|l|}
\hline $\begin{array}{c}\text { Levels of } \\
\text { Thinking }\end{array}$ & $\begin{array}{c}\text { Degree of } \\
\text { Levels }\end{array}$ & $\begin{array}{c}\text { Bloom's } \\
\text { Taxonomy }\end{array}$ & \multicolumn{1}{|c|}{$\begin{array}{c}\text { Description of Bloom's } \\
\text { Taxonomy }\end{array}$} \\
\hline Level 1 & Lowest & Knowledge & $\begin{array}{l}\text { Echo (recall) the same } \\
\text { content (knowledge) }\end{array}$ \\
\hline Level 2 & & Comprehension & Understanding the content \\
\cline { 5 - 5 } Level 3 & \multirow{2}{*}{ Intermediate } & Application & $\begin{array}{l}\text { Apply content (knowledge) } \\
\text { in new situation }\end{array}$ \\
\cline { 1 - 1 } Level 4 & & Analysis & $\begin{array}{l}\text { Break down the content } \\
\text { (knowledge) }\end{array}$ \\
\cline { 4 - 5 } Level 5 & & Synthesis & $\begin{array}{l}\text { Reassemble contents } \\
\text { together }\end{array}$ \\
\hline Level 6 & Highest & Evaluation & $\begin{array}{l}\text { Justify with his own thinking } \\
\text { beyond the content }\end{array}$ \\
\hline
\end{tabular}

Though Bloom's Taxonomy has six levels of thinking, but if we consider the degree of thinking levels then both model is identical (see Table 3). Hence, for the experiment purpose only the Lee's Model is considered in this paper.

Table 3. Comparison between Bloom's Taxonomy \& Lee's Model

\begin{tabular}{|c|c|c|c|}
\hline $\begin{array}{l}\text { Levels of } \\
\text { Thinking }\end{array}$ & $\begin{array}{c}\text { Degree of } \\
\text { Levels }\end{array}$ & $\begin{array}{c}\text { Bloom's } \\
\text { Taxonomy }\end{array}$ & $\begin{array}{l}\text { Description of Bloom's } \\
\text { Taxonomy }\end{array}$ \\
\hline Level 1 & Lowest & Knowledge & Recall \\
\hline Level 2 & \multirow{4}{*}{ Intermediate } & Comprehension & \multirow{4}{*}{ Rationalization } \\
\hline Level 3 & & Application & \\
\hline Level 4 & & Analysis & \\
\hline Level 5 & & Synthesis & \\
\hline Level 6 & Highest & Evaluation & Reflectivity \\
\hline
\end{tabular}

\section{B. Data Sets}

In this experiment 31 graduate students of almost same age actively participate from the same class. They are given 4 poster presentation in 4 groups on the wiki where they participated in three categories of Q/A. Table 4 presents the description about all three categories of Q/A and Fig. 1 shows a sample poster presentation given on the wiki.

Table 4. Q/A Posting Pattern

\begin{tabular}{|c|l|l|}
\hline Q/A Category & \multicolumn{1}{|c|}{ Q/A Posting Type } & \multicolumn{1}{|c|}{ Q/A Posting Description } \\
\hline $\begin{array}{c}\text { First Category } \\
\text { of Q/A }\end{array}$ & $\begin{array}{l}\text { Comment, suggest or } \\
\text { ask questions on any } \\
\text { aspect of presentation }\end{array}$ & $\begin{array}{l}\text { First Post or initial post based } \\
\text { on the poster presentation the } \\
\text { wiki }\end{array}$ \\
\hline $\begin{array}{c}\text { Second } \\
\text { Category of } \\
\text { Q/A }\end{array}$ & $\begin{array}{l}\text { Justify or defend } \\
\text { points in presentation }\end{array}$ & $\begin{array}{l}\text { Justification of first post (first } \\
\text { category of Q/A) }\end{array}$ \\
\hline $\begin{array}{c}\text { Third } \\
\text { Category of } \\
\text { Q/A }\end{array}$ & Further clarification & $\begin{array}{l}\text { Further clarification or } \\
\text { comments against the } \\
\text { justification post (second } \\
\text { category of Q/A) }\end{array}$ \\
\hline
\end{tabular}

Based on the poster presentations on the wiki, students post their Q/A. All the Q/A of these 4 poster presentation on the wiki is then analyzed according to Lee's Model to prepare the data sets. The Fig. 2 presents a sample data set.

\section{Data Analysis}

Content (poster presentation) analysis method was used to analyze the qualitative data. Students post their thinking into three categories of Q/A (see Table 4) based on the poster presentation on the wiki. Then their post has been analyzed according to the Lee's model of thinking levels (see Table 1). Table 5 shows how these data is analyzed according to Lee's Model and given a weight to each post. The weights of thinking levels of students are then analyzed from different directions to justify the research question "Can wiki-based reflection as an ICT tool be used to promote thinking level". The findings or outcomes of the analysis are presented in the "Results \& Discussions" section.

Table 5. Data Analysis According to Lee's Model

\begin{tabular}{|l|c|c|}
\hline \multicolumn{1}{|c|}{ Analysis of Students Post } & Thinking Levels & Weights \\
\hline $\begin{array}{l}\text { If student' post echo or recall the same } \\
\text { content on the poster presentation }\end{array}$ & Recall & 1 \\
\hline $\begin{array}{l}\text { If student' post rationalize his or her } \\
\text { thinking with the content on the poster } \\
\text { presentation }\end{array}$ & Rationalization & 2 \\
\hline $\begin{array}{l}\text { If student' post reflect his own thinking } \\
\text { beyond the content on the poster } \\
\text { presentation }\end{array}$ & Reflectivity & 3 \\
\hline
\end{tabular}

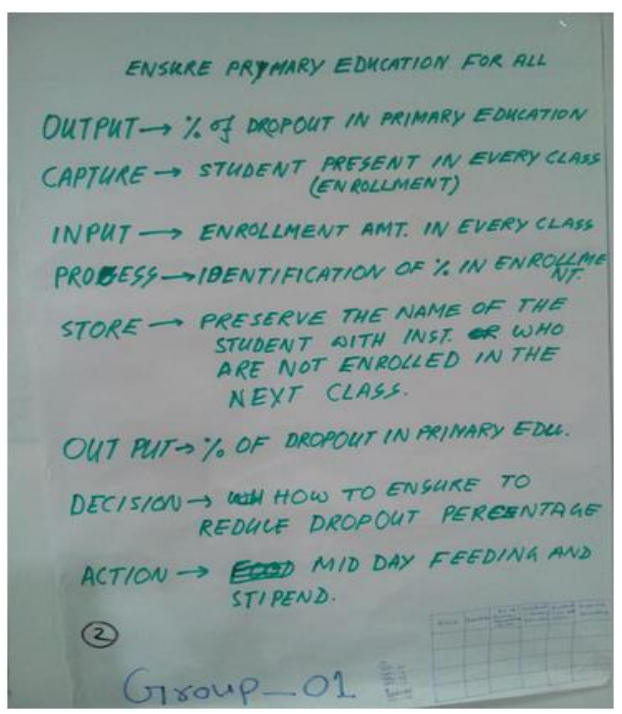

Fig.1. Sample Poster Presentation on the Wiki.

\section{RESULTS \& DISCUSSIONS}

In this section the findings and results of the experiments have been discussed to show how student can improve their thinking levels into deeper levels.

In the experiment, we can see that most of the student in their first post are just recall the same content on the poster but when they post second time or third time based on the same poster, their thinking level are increased. To address this finding through the experiment, we have collected data of 22 students, where all 22 students post at 
least two posts on the same poster, that means, participated in both first post (first category of Q/A) and further clarification (third category of $\mathrm{Q} / \mathrm{A}$, which is the further clarification of second category of Q/A). The Fig. 3 shows that their thinking level is increased in the third category of Q/A in comparison with the first post according to the Lee's Model of thinking levels. That means, in most of the cases in their first post, they just echo (recall) the same thing (content) on the poster presentation but in the further clarification post most of the time they reflect their own thinking beyond the contents on the poster presentation. That means, increases of their thinking level in their third post in comparison with their initial (first) post.

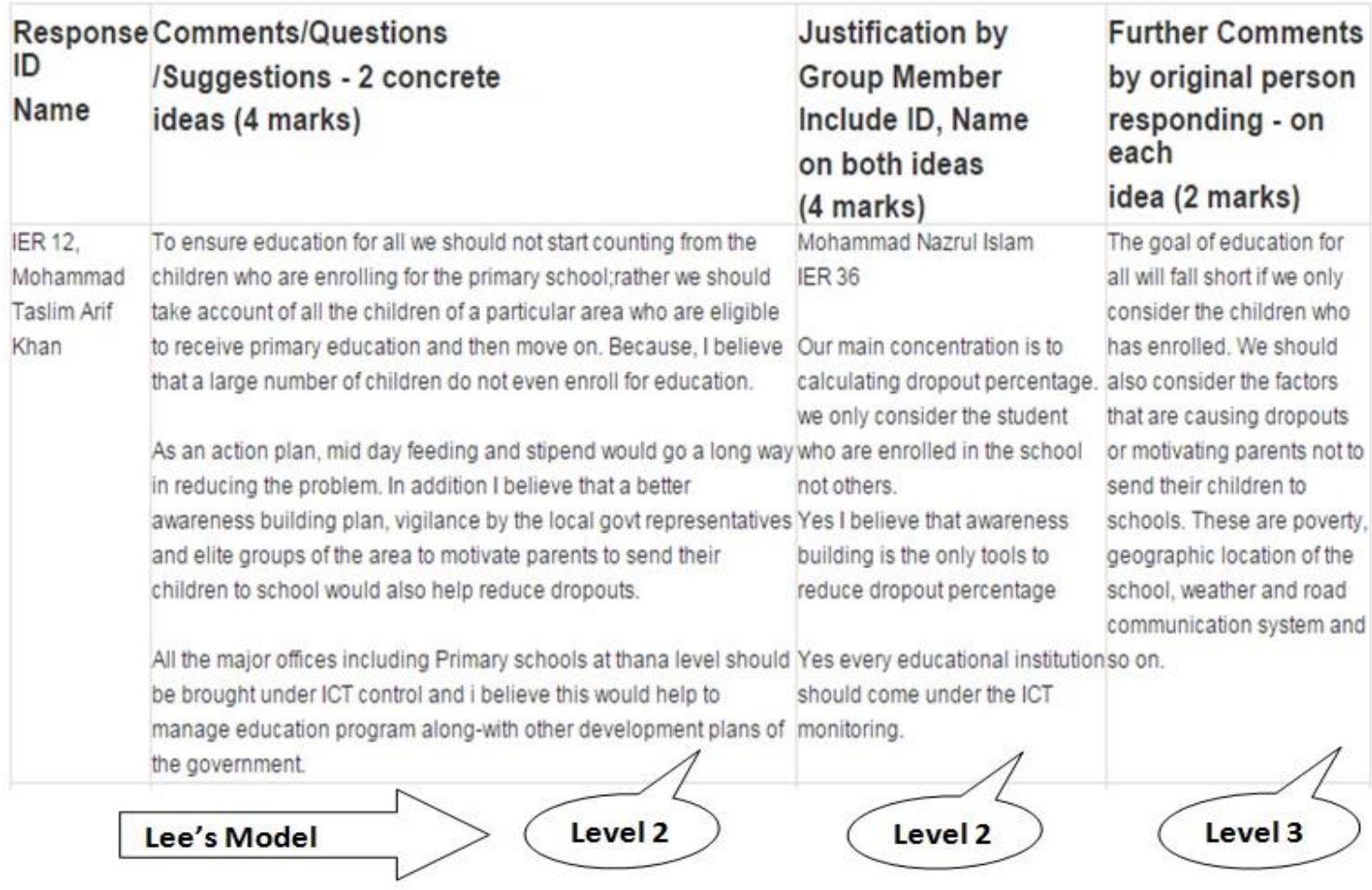

Fig.2. Sample Data Set based on a Poster Presentation on the Wiki.

Moreover, if we combined the student posts as Post1 (first time post), Post2 (second time post), and Post3 (third time post), then we can see that most of the students thinking in Recall and Rationalization level in their first post (Post1) but very few numbers are in Reflectivity level (which is highest level of thinking). However, if we consider the third time post (Post3), we can see that most of the students are in Rationalization and Reflectivity level (higher levels of thinking) and least number of students is in Recall level (lowest level of

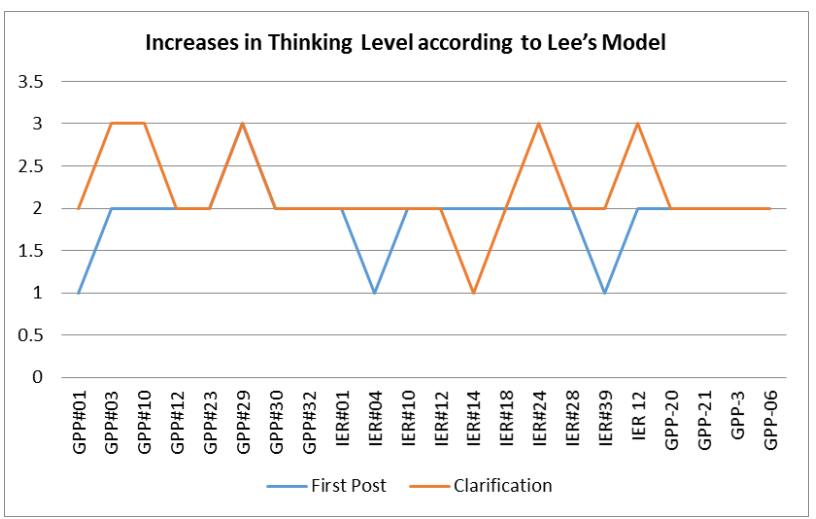

Fig.3. Comparison of first post with further clarification post. thinking). That means students are moving into higher levels of thinking according to Lee's Model. Fig. 4 represents these finding. Furthermore, consider only the Reflectivity level (higher levels of thinking) of Pos1, Post2, and Post 3 in the Fig. 4, which shows that the number of student in Reflectivity level is increasing from Post 1 to Post 2 and also from Post 2 to Post 3 . That means they are moving towards Reflectivity level (higher levels of thinking). More precisely we can see the increasing trends of reflectivity level in Fig. 5 where it is clear that

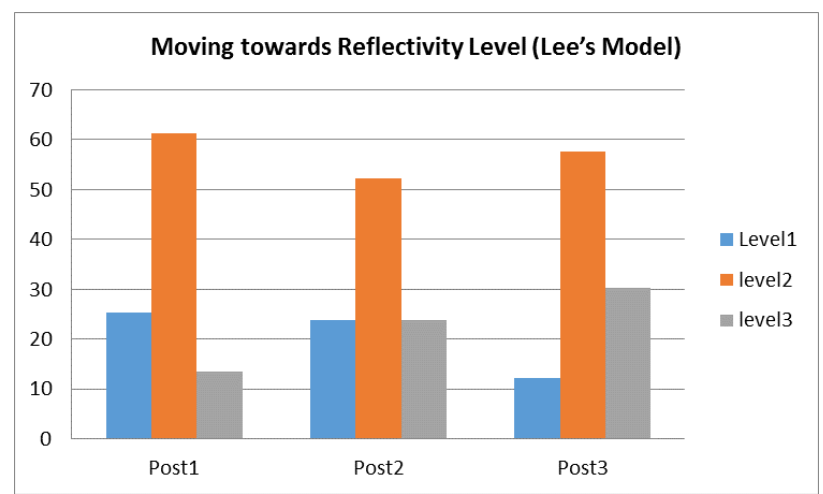

Fig.4. Comparison of students thinking levels in terms of Post1, Post2, and Post3. 
the trend of reflectivity level of the students is increasing in terms of Post1, Post2, and Post3.

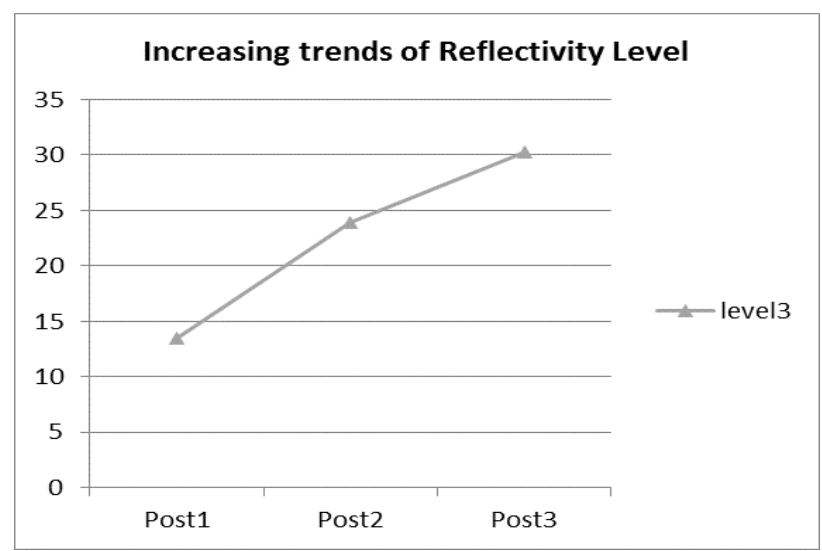

Fig.5. Changes of Reflectivity level (Level 3) in terms of Post1, Post2, and Post 3 .

According to the data set of all four poster presentations, we have counted the total weights of each category of Q/A posted by the students to see the average level of thinking of all students in terms of Post1, Post2, and Post3. From this calculation we can see that the average weights of First post/First category of Q/A (Comment, suggest or ask questions) is lower than the second category of Q/A (Justification post) and Second category of Q/A is lower than the Third category of Q/A (Further comments or clarification post). That mean the average thinking levels of students is increasing according to the increases of their number of posing which is outlined in Table 6 and Fig. 6.

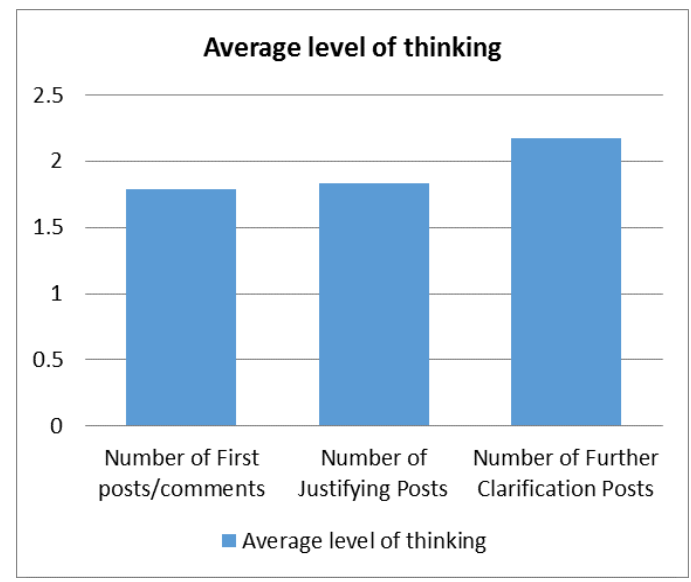

Fig.6. Average level of thinking of all students.

Table 6. Average level of thinking of all students.

\begin{tabular}{|l|c|c|}
\hline \multicolumn{1}{|c|}{ Analysis of Students Post } & Thinking Levels & Weights \\
\hline $\begin{array}{l}\text { If student' post echo or recall the same } \\
\text { content on the poster presentation }\end{array}$ & Recall & 1 \\
\hline $\begin{array}{l}\text { If student' post rationalize his or her } \\
\text { thinking with the content on the poster } \\
\text { presentation }\end{array}$ & Rationalization & 2 \\
\hline $\begin{array}{l}\text { If student' post reflect his own thinking } \\
\text { beyond the content on the poster } \\
\text { presentation }\end{array}$ & Reflectivity & 3 \\
\hline
\end{tabular}

Table 7. Eight dimensions of blended learning in terms of our wikibased model.

\begin{tabular}{|c|l|}
\hline $\begin{array}{c}\text { Eight } \\
\text { dimensions of } \\
\text { blended learning }\end{array}$ & \multicolumn{1}{|c|}{ Our Proposed Model as Blended Learning } \\
\hline Delivery & $\begin{array}{l}\text { Different modes (face-to-face and distance } \\
\text { education) }\end{array}$ \\
\hline Technology & Web based (wiki in our case) \\
\hline Chronology & $\begin{array}{l}\text { Synchronous (in case of face-to-face mode) and } \\
\text { asynchronous (in case of distance mode) } \\
\text { involvements }\end{array}$ \\
\hline Locus & $\begin{array}{l}\text { Problem-based and Practice-based settings to } \\
\text { promote deeper thinking level }\end{array}$ \\
\hline Roles & Individual and Grouping based \\
\hline Pedagogy & $\begin{array}{l}\text { Problem-based approach, Assessment-based } \\
\text { approach, and Collaborative learning strategy }\end{array}$ \\
\hline Focus & Deeper thinking level \\
\hline Direction & $\begin{array}{l}\text { Instructor-directed and learner-directed learning } \\
\text { based on practices to promote deeper thinking level }\end{array}$ \\
\hline
\end{tabular}

As increase in the level of thinking is progressive, we can propose our model to be followed by blended learning - classroom support by following on with online reflection. Many Researchers identified that the term blended learning is subject to multiple definitions [17, 24, 21]. But then eight dimensions of different blends were well identified in a UK wide review of undergraduate experience of blended learning [24]. For our proposed model we have also identified these eight dimensions to be followed by blended learning (see Table 7). Table 7 shows that the proposed model in this paper fulfills all the eight dimensions of blended learning model to be followed by blended learning. Hence we can conclude our wiki-based model as a blended learning model to promote deeper thinking level of students in higher education.

\section{CONCLUSIONS}

Online-based support to classroom education, i.e., a form of blended learning is growing day by day all over the world, more specifically in higher education where ICT tools can be very effective for reflective learning. Because, higher education means to acquires necessary skills to be a real world problem solver and a critical thinker. In higher education class group presentation is one of the most common activities, which is very much involved with students thinking ability. In this research work, a wiki was chosen as an ICT tool where class presentation is posted as a poster for online discussion. The findings of this research works shows that

a) individual student thinking level is increased according to the Lee's Model of thinking in comparison between their first post and clarification post (further comment or post).

b) their levels of thinking are moving towards the reflectivity level (highest levels of thinking) according to Lee's Model of thinking levels. 
c) average levels of thinking of all students are moving towards reflectivity level according to Lee's Model.

Thus, ICT tools can be used in higher education to support regular existing face-to-face classroom presentation activities, where simple questions/answers may be used to enhance/scaffold levels of thinking. Additionally, these thinking activities can easily take place outside the direct contact hours in student's own time. Besides this, social media ICT tools can be used to support this active learning activity.

\section{REFERENCES}

[1] H. S. Barrows, "Problem-based learning in medicine and beyond: A brief overview", in New Directions for Teaching and Learning, vol. 68, pp. 3-12, 1996.

[2] D. Boud, R. Keogh, and D. Walker, "Reflection: Turning Experience into Learning", London and New York: RoutledgeFalmer, 2005.

[3] A. Brockbank and I. McGill, "Facilitating Reflective Learning in Higher Education". Buckingham: SRHE and Open University, 1998.

[4] J. Calderhead and P. Gates, "Conceptualizing in Teacher Development", London, Washington, D. C.: The Falmer Press, 1993.

[5] J. Chaffee, "Thinking critically" (4th ed.). Boston: Houghton Mifflin, 1994.

[6] B. J. Duch, "Writing problems for deeper understanding", in B. J. Duch, S. E. Groh, \& D. E. Allen (Eds.), The power of problem-based learning, pp. 47-53. Sterling, VA: Stylus Publishing, 2001

[7] S. A. Gallagher, "Problem-based learning: Where did it come from, what does it do, and where is it going?" in Journal for the Education of the Gifted, vol. 20(4), pp. 332-362. 1997.

[8] Blended Learning 101: Handbook, Url: http://learningaccelerator.org/media/3d90f736/Blended_Le arning_Handbook_6713_Final.pdf. Aspire Publication School. Last accessed: 6 September 2016.

[9] C. E. Hmelo and M. Ferrari, M., "The problem-based learning tutorial: Cultivating higher order thinking skills", in Journal for the Education of the Gifted, vol. 20(4), pp. 401-422, 1997.

[10] Judy Thompson, "Blended Learning - It's What's Up For Successful Students", 1996, Url: https://elearningindustry.com/6-blended-learning-modelsblended-learning-successful-students, Last accessed: 6 September 2016.

[11] D. W. Johnson, D. and F. P. Johnson, "Joining together: Group theory and group skills", Boston, MA: Allyn Bacon, 2002.

[12] S. Karayan and J. Crowe, "Student perspectives of electronic discussion groups", in THE Journal: Technological Horizons in Education, vol. 24(9), pp. 6971, 1997.
[13] Lee, "Lee's Model of thinking level", 2000.

[14] J. Loughran, "Developing Reflective Practice: Learning about Teaching and Learning Through Modelling. London", Falmer Press, 1996.

[15] J.A. Moon, J. A., "Reflection in Learning and Professional Development", Theory and Practice, London and New York: RoutledgeFalmer, 1999.

[16] K. F. Osterman and R. B., Kottkamp, "Reflective Practice for Educators", Professional Development to Improve Student Learning, California: Corwin Press, 2004.

[17] M. Oliver, M. and K. Trigwell, "Can 'blended learning' be redeemed?", in E-Learning. Vol. 2 (1), pp. 17-26, 2005.

[18] A. Pincas, G. Saunders, and G. Hughes, "FINAL REPORT Effective use of learning technologies (ICT) with campusbased students", Institute of Education, University of London, 2003.

[19] B. Rosenshine, "Recent research on teaching behaviors and student achievement", in Journal of Teacher Education, vol. 27(1), pp. 61-64, 1976.

[20] J. Rossbottom, "Hybrid Learning - a safe route into web based open and distance learning for the computer science teacher", in Proceedings of the 6th annual conference on Innovation and technology in computer science education, Canterbury, United Kingdom, ACM Press, New York, NY, USA, 2001

[21] G. Salmon, "Flying not flapping: A strategic framework for e-learning and pedagogical innovation in higher education institutions ALT-J", in Research in Learning Technology, vol. 13 (3), pp. 201-218, 2005.

[22] D. Schön, "The Reflective Practitionier", How professionals think in action. Great Britain, London: Maurice Temple Smith Ltd, 1991.

[23] D. Schuman, "Direct Instruction: A Review of Research", Master's thesis, University of North Carolina at Wilmington, Watson School of Education, 1998, Retrieved fromhttp://people.uncw.edu/kozloffm/shumanthesisdi.html.

[24] Rhona Sharpe, Greg Benfield, George Roberts and Richard Francis, "The undergraduate experience of blended e-learning: a review of UK literature and practice", in Higher Education Academy, 2006.

[25] D. Smith and G. Hardaker, "e-Learning innovation through the implementation of an Internet supported learning environment. Educational Technology and Society, vol. 3, pp. 1-16, 2000.

[26] Heather Staker and Michael B. Horn, "Classifying K-12 Blended learning", INNOSIGHT INSTITUTE, 2012.

[27] J. C. Sweeney and D. Ingram, "A comparison of traditional and web-based tutorials in marketing education: An exploratory study", in Journal of Marketing Education vol. 23(1), pp. 55-62, 2001.

[28] P. Woodworth and A. A. G., "A hybrid structure for the introductory computers and information technology course," in Journal of Computing Sciences in Colleges, vol. 22(3), pp. 136- 144, 2007.

[29] B. Yıldırım and S. Özkahraman, "Critical Thinking in Nursing and Learning Styles", in International Journal of Humanities and Social Science, vol. 1(18), pp. 127-133, 2011. 


\section{Authors' Profiles}

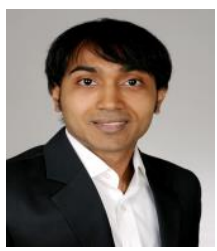

Akinul Islam Jony born in Dhaka, Bangladesh. He received his M.Sc. degree in Infromatics at Technical University of Munich (TUM) in Germany. Previously he completed his B.Sc. degree in Computer Science at American International University - Bangladesh (AIUB) and Master degree in Information Technology at University of Dhaka (DU) in Bangladesh.

At present he is working as an Assistant Professor in the department of Computer Science at American International University - Bangladesh (AIUB). His current research interest includes e-learning, big data, machine learning, and service computing.

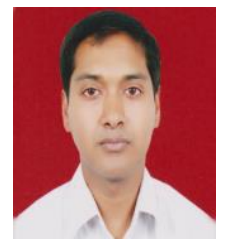

Md. Sadekur Rahman has obtained his Bachelor and Master degree in Applied Mathematics and Informatics from Peoples' Friendship University of Russia. Currently he is continuing his $\mathrm{PhD}$ in Computer Science at the University Sains Islam Malaysia.

At present he is working as a Senior Lecturer in the department of Compute Science and Engineering in Daffodil International University, Bangladesh. Mr. Rahman has a number of publications in international and national journals and conference proceedings. His research interest includes Data mining, Pattern Recognition, Neural Network, Machine Learning and Natural Language Processing.

$\mathrm{He}$ is involved with workshop on Participatory Engaging Techniques (PET) which guides newly joined faculties of DIU for preparing for their teaching career. He is also engaged in research on Guided Classroom Techniques for ensuring quality education for last three years.

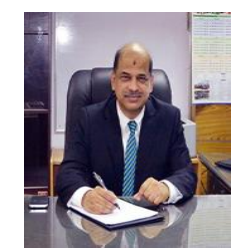

Yousuf Mahbubul Islam completed his PhD (1988) from Strathclyde University, Glasgow, UK, in Design, Manufacturing \& Engineering Management. He was recipient of a David Livingstone award as well as a Charles Wallace award during his $\mathrm{PhD}$ research. Having stood first in his Master's class he was recommended for an automatic transfer to the $\mathrm{PhD}$ program at Strathclyde University. He completed his Bachelor's Degree in Electrical \& Electronic Engineering from Heriot-Watt University in Edinburgh in 1978 with $100 \%$ marks for his software project.

At present he is working as a vice chancellor at Daffodil International University (DIU) since July, 2105. Also, he is a full time professor in the department of software engineering at DIU.

The idea of teaching programming using participatory teaching techniques and using social media to solve learning gaps was born out of the teaching experiences of Dr Islam - the Bangladesh Project Leader of the LEADHER project. Given his keen interest in helping students learn, he contributed to various other researches e.g., low-cost interactive distance education without the use of Internet, low cost data collection from remote rural regions, collection and delivery of agricultural market information from rural regions, low cost order, distribution management and sales monitoring in rural areas, secure national voting through mobile phones, e-learning, m-learning and participatory techniques that transfer ownership, use of Mind Maps in student counseling, psychological counseling, use of participatory techniques in distance education and face to face classrooms.

How to cite this paper: Akinul Islam Jony, Md. Sadekur Rahman, Yousuf Mahbubul Islam,"ICT in Higher Education: Wiki-based Reflection to Promote Deeper Thinking Levels", International Journal of Modern Education and Computer Science(IJMECS), Vol.9, No.4, pp.43-49, 2017.DOI: 10.5815/ijmecs.2017.04.05 